\title{
Penerapan Metode Pembelajaran EPA (Eksplorasi, Pengenalan, dan Aplikasi Konsep) dalam Meningkatkan Hasil Belajar Siswa SMP Negeri 8 Donggo Satap Materi Operasi Bilangan Pecahan
}

\author{
Susisusanti $^{1}$, Ika Wirahmad ${ }^{2 *}$, Syarifuddin ${ }^{2}$ \\ ${ }^{1}$ Mahasiswa Prodi Pendidikan Matematika, STKIP Bima, Kota Bima, Indonesia \\ ${ }^{2}$ Dosen Prodi Pendidikan Matematika, STKIP Bima, Kota Bima, Indonesia
}

*Coresponding Author: wirahmad.71@gmail.com

\begin{tabular}{ll}
\hline \hline Article history & Rendahnya hasil belajar matematika siswa kelas VII-A SMP N 8 \\
\hline Dikirim: & Donggo Satap diduga salah satu penyebabnya adalah masih \\
31-12-2021 & banyak siswa yang mengalami kesulitan dalam memahami \\
Direvisi: & konsep matematika yang diajarkan. Serta dalam menyampaikan \\
02-01-2022 & materi pelajaran, guru lebih banyak menerapkan metode ceramah \\
Diterima: & yang sifatnya monoton dan kurang variatif. Akibatnya siswa \\
03-01-2022 & menjadi kurang aktif dan hanya menerima apa yang diberikan \\
Key words: & oleh guru serta mengerjakan tugas sesuai dengan apa yang \\
\hline metode EPA; & diminta oleh guru. Oleh karena itu, guru perlu mencari metode \\
hasil belajar matematika; & pembelajaran yang lebih baik sehingga dalam proses \\
bilangan pecahan & pembelajaran yang diusahakan dapat meningkatkan hasil belajar \\
& siswa, salah satunya dengan metode EPA.Tujuan penelitian ini \\
& adalah untuk meningkatkan hasil belajar siswa melalui metode \\
& EPA. Jenis penelitian ini adalah penelitian tindakan kelas (PTK) \\
& yang berlangsung dalam tiga siklus. Penelitian ini menggunakan \\
& metode EPA (Eksplorasi, Pengenalan dan Aplikasi konsep). \\
& Teknik pengumpulan data yang digunakan adalah tes dan \\
& observasi. Teknik analisis data menggunakan analisis kualitatif. \\
& Berdasarkan hasil penelitian menunjukkan adanya peningkatan \\
ketuntasan belajar dari nilai rata-rata siswa pada siklus I sebesar & 70.51 dengan persentase sebesar 74.28\% dan nilai rata-rata pada \\
& siklus II sebesar 73.82 dengan persentase sebesar 80\% serta nilai \\
& rata-rata pada siklus III sebesar 80.05 dengan persentase 88.57\%. \\
& Jadi dapat disimpulkan bahwa penerapan metode pembelajaran \\
& EPA (Ekplorasi, Pengenalan, dan Aplikasi Konsep) materi \\
& Operasi pada bilangan pecahan dapat meningkatkan hasil belajar \\
& matematika siswa. \\
\hline \hline
\end{tabular}

\section{PENDAHULUAN}

Matematika adalah ilmu dasar yang memiliki peranan yang sangat penting dalam perkembangan ilmu pengetahuan. Hal ini dikarenakan kemajuan dan perkembangan ilmu pengetahuan dan teknologi yang sangat pesat, menjadikan menempatkan posisi pendidikan sebagai penentu bagi kemajuan ilmu pengetahuan dan teknologi dimasa selanjutnya (Adi, 2011). Salah satu upaya untuk meningkatkan mutu pendidikan di sekolah adalah memperbaiki proses pembelajaran. Berbagai metode dan strategi baru dalam proses pembelajaran di sekolah telah muncul dan berkembang seiring dengan perkembangan ilmu pengetahuan dan teknologi.

Proses belajar mengajar matematika ternyata tidak hanya model pembelajaran dan media saja yang berpengaruh namun minat juga sangat besar peranannya 
terhadap meningkatkan hasil belajar siswa. Karena dengan adanya minat belajar dapat menumbuhkan minat belajar siswa. Bagi siswa yang memiliki minat belajar yang kuat akan mempunyai keinginan untuk melaksanakan kegiatan belajar mengajar. Sehingga boleh jadi siswa yang memiliki intelegensi yang cukup tinggi menjadi gagal karena kurangnya minat belajar, sebab hasil belajar itu akan optimal bila terdapat minat belajar yang baik (Hamalik, 2010; Nurwadani, 2021).

Tingkat hasil belajar adalah suatu yang diperoleh berupa kesan-kesan yang mengakibatkan perubahan dalam diri individu sebagai hasil dari aktifitas belajar (Hamdani, 2011; Murtalib dkk, 2020; Dusalan dkk, 2021). Pada penelitian ini yang dimaksud adalah hasil perubahan dalam diri siswa sebagai hasil belajar matematika. Minat belajar matematika adalah suatu rasa lebih suka dan rasa ketertarikan pada bidang studi matematika, tanpa ada yang menyuruh (Slameto, 2010; Sutarto \& Syarifuddin, 2013).

Menurut WJS Poerdarminta dikutip dari Nelly Maghfiroh (2010) berpendapat, bahwa hasil belajar adalah hasil yang telah dicapai (dilakukan, dikerjakan, dan lain sebagainya). Sedangkan menurut Gagne (Yushniyah, 2010) meningkatkan hasil belajar adalah penguasan siswa terhadap materi pelajaran tertentu yang telah diproleh dari hasil tes belajar yang telah dinyatakan dalam bentuk skor.

Proses belajar seorang siswa akan mengalami perubahan Tingkah laku sebagai akibat dari pengalaman-pengalaman yang diperolehnya untuk mencapai prestasi maksimal. Slameto (2010) mengemukakan bahwa belajar adalah suatu proses usaha yang dilakukan seseorang untuk memperoleh suatu perubahan tingkah laku yang baru secara keseluruhan, sebagai hasil pengalaman sendiri dalam interaksi dengan lingkungannya.

Berdasarkan wawancara dengan guru bidang studi matematika pada saat observasi awal, rendahnya hasil belajar siswa kelas VII-A di SMP Negeri 8 Donggo Satap bahwa meningkatkan hasil belajar matematika siswa masih jauh dari harapan disebabkan karena masih banyak siswa yang mengalami kesulitan dalam memahami konsep matematika yang diajarkan.

Hasil belajar siswa masih rendah disebabkan oleh beberapa faktor antara lain, faktor internal siswa seperti kesiapan siswa, minat, motivasi, dan kemampuan awal siswa dan faktor ekternal seperti metode dan pendekatan yang diterapkan oleh guru. Proses pembelajaran secara klasikal, banyak metode atau teknik mengajar yang digunakan guru. Metode atau teknik yang digunakan oleh guru seringkali merupakan gabungan dari berbagai metode. Namun berdasarkan data yang dijumpai pada saat observasi awal, masih banyak siswa yang mengalami kesulitan (berprestasi rendah) dalam mempelajari materi Operasi Pada Bilangan Pecahan, seperti yang terdapat di kelas VII-A SMP Negeri 8 Donggo Satap.

Kesulitan siswa kelas VII-A dalam memahami materi operasi pada bilangan pecahan disebabkan karena kurangnya pemahaman tentang cara menemukan rumus Operasi Pada Bilangan Pecahan dan kurangnya pemahaman dalam membedakan sifat-sifat Operasi Pada Bilangan Pecahan. Hal ini karena pada saat penyampaian materi siswa hanya diberikan contoh di papan tulis dan langsung memberikan rumus dan sifat-sifat Operasi Pada Bilangan Pecahan, tanpa adanya interaksi langsung terhadap objek yang dibicarakan. 


\section{KAJIAN TEORI}

\section{Proses Belajar Mengajar}

Belajar dan mengajar merupakan dua konsep pokok yang tidak bisa dipisahkan satu dengan yang lainnya. Belajar merujuk pada apa yang harus dilakukan seseorang sebagai subyek yang menerima pelajaran (sasaran didik), sedangkan mengajar menunjukkan apa yang dilakukan guru sebagai pengajar.

Teori belajar yang lain adalah purposeful learning. purposeful learning adalah belajar yang dilakukan dengan sadar untuk mencapai tujuan dan dilakukan siswa sendiri tanpa bimbingan orang lain didalam situasi sekolah. purposeful learning oleh siswa sendiri maksudnya adalah kegiatan belajar tanpa bimbingan orang lain, dimana individu memperoleh banyak pengetahuan. Purposeful learning dengan bimbingan maksudnya siswa mendapat bimbingan guru untuk memahami suatu konsep. Hal ini dilakukan guru dengan cara menyediakan sumber-sumber belajar yang mengatur kegiatan belajar mengajar. purposeful learning dengan bimbingan dapat mengembangkan pengetahuan yang komperhensif menurut pengalaman belajar yang produktif selama waktu yang cukup lama (Slameto, 2003).

Menurut Alvin W. Howard teori mengajar adalah suatu aktifitas untuk mencoba menolong, membimbing seseorang untuk mendapatkan, merubah atau mengembangkan skill, atitude, ideals (cita-cita), apreciations (penghargaan) dan knowledge. Dalam pengertian ini guru harus berusaha membawa perubahan tingkah laku yang baik untuk merubah tingkah laku siswanya. (Slameto, 2003; Sartika dkk, 2020).

\section{Hasil Belajar}

Masalah belajar adalah masalah bagi setiap manusia, dengan belajar manusia memperoleh keterampilan, kemampuan sehingga terbentuklah sikap dan bertambahlah ilmu pengetahuan. Jadi hasil belajar itu adalah suatu hasil nyata yang dicapai oleh siswa dalam usaha menguasai kecakapan jasmani dan rohani di sekolah yang diwujudkan dalam bentuk raport pada setiap semester. Untuk mengetahui perkembangan sampai di mana hasil yang telah dicapai oleh seseorang dalam belajar, maka harus dilakukan evaluasi. Untuk menentukan kemajuan yang dicapai maka harus ada kriteria (patokan) yang mengacu pada tujuan yang telah ditentukan sehingga dapat diketahui seberapa besar pengaruh strategi belajar mengajar terhadap keberhasilan belajar siswa. Hasil belajar siswa menurut Winkel (2007) adalah keberhasilan yang dicapai oleh siswa, yakni prestasi belajar siswa di sekolah yang mewujudkan dalam bentuk angka.

Menurut Surakhmad \& Jemmars, (2020) hasil belajar siswa bagi kebanyakan orang berarti ulangan, ujian atau tes. Maksud ulangan tersebut ialah untuk memperoleh suatu indek dalam menentukan keberhasilan siswa.

Hasil belajar adalah perubahan perilaku yang terjadi setelah mengikuti pembelajaran sesuai dengan tujuan pendidikan dalam domain kognitif, afektif dan psikomotorik (Purwanto, 2011; Syarifuddin, 2019, Imayanti dkk, 2021). Dalam domain kognitif diklasifikasikan menjadi kemampuan hapalan, pemahaman, penerapan, analisis, sintesis, dan evaluasi. Dalam domain afektif hasil belajar meliputi level penerimaan, partisipasi, penilaian, organisasi, dan karakterisasi. Sedang domain psikomotorik terdiri dari level persepsi, kesiapan, gerakan terbimbing, gerakan terbiasa, gerakan kompleks dan kreativititas. 
Hasil belajar berupa perubahan perilaku, baik yang menyangkut kognitif, psikomotorik, maupun afektif (Aqib, 2010; Atmarita, \& Syarifuddin, 2021). Karena menurut Driscoll (Smaldino, 2011) belajar didefinisikan sebagai perubahan terus menerus dalam kemampuan yang berasal dari pengalaman pembelajardan interaksi pembelajar dengan dunia.

Uraian di atas disimpulkan bahwa hasil belajar adalah perubahan tingkah laku peserta didik yang terjadi setelah mengikuti pembelajaran. Perubahan tersebut meliputi aspek kognitif (kemampuan hapalan, pemahaman, penerapan, analisis, sintesis, dan evaluasi), afektif (penerimaan, partisipasi, penilaian, organisasi, dan karakterisasi) dan psikomotorik (persepsi, kesiapan, gerakan terbimbing, gerakan terbiasa, gerakan kompleks dan kreativititas). Hasilnya dituangkan dalam bentuk angka atau nilai.

Definisi diatas, maka dapat diambil kesimpulan bahwa hasil belajar adalah prestasi belajar yang dicapai siswa dalam proses kegiatan belajar mengajar dengan membawa suatu perubahan dan pembentukan tingkah laku seseorang. Untuk menyatakan bahwa suatu proses belajar dapat dikatakan berhasil, setiap guru memiliki pandangan masing-masing sejalan dengan filsafatnya. Namun untuk menyamakan persepsi sebaiknya kita berpedoman pada kurikulum yang berlaku saat ini yang telah disempurnakan, antara lain bahwa suatu proses belajar mengajar tentang suatu bahan pembelajaran dinyatakan berhasil apabila tujuan pembelajaran khususnya dapat dicapai.

\section{Metode Pembelajaran EPA}

Metode merupakan suatu cara yang dipergunakan untuk mencapai tujuan yang telah ditetapkan. Metode secara harfiah berarti "cara". Dalam pemakaian umum, metode diartikan sebagai suatu cara atau prosedur yang dipakai untuk mencapai tujuan tertentu. Sedangkan kata mengajar berarti "memberi pelajaran".

Metode mengajar adalah cara penyajian bahan pelajaran kepada siswa untuk tercapainya tujuan yang telah ditetapkan (Pupuh, 2007). Definisi lain metode pembelajaran (Slameto, 2010), yaitu jalan atau cara yang harus dilalui untuk mencapai suatu tujuan belajar yaitu untuk mendapatkan pengetahuan, sikap. kecakapan, dan keterampilan.

Metode EPA pertama kali diperkenalkan oleh Rudi Prakanto, menurutnya metode ini menekankan pada cara belajar sesuai dengan pengetahuan awal siswa. Ide dasar pemikirannya adalah siswa secara aktif membangun pengetahuan dengan cara terus menerus menemukan sendiri melalui kegiatan nyata di sekolah. Pelaksanaan pembelajaran dengan metode EPA melalui tiga tahap yaitu eksplorasi, tahap pengenalan, dan tahap aplikasi konsep (Dwi, 2008).

1. Tahap eksplorasi bertujuan untuk menggali fakta-fakta dan konsep yang telah dimiliki siswa. Pada tahap ini guru memberikan tes awal yang bertujuan untuk mengetahui sampai mana batas pengetahuan awal yang telah dimiliki siswa yang dapat dijadikan dasar untuk menerima program pembelajaran yang akan diberikan.

2. Tahap pengenalan konsep berupa kegiatan eksperimen untuk memecahkan masalah yang diajukan siswa. Tahap pengenalan konsep menurut teori Van Hiele (Depdiknas, 2004) biasa disebut tingkat visualisasi. Dimana pada tingkat ini siswa mengamati suatu bangun sebagai suatu keseluruhan, sesuatu yang 
wholistic. Pada tahap ini kegiatan yang dilakukan adalah memecahkan masalah yang muncul pada tahap eksplorasi.

3. Tahap aplikasi konsep berupa pekerjaan soal-soal berdasarkan hasil eksperimen, yang memungkinkan adanya penerapan dalam kehidupan sehari-hari. Aplikasi konsep berfungsi untuk memperkuat ingatan siswa atau daya simpan informasi. Hal ini sejalan dengan apa yang dikemukakan oleh Sudjana (2009), bahwa prinsip aplikasi penting untuk menggapai hasil belajar siswa yang tahan lama dan sifatnya integral tiga ranah pendidikan yaitu pengetahuan, sikap dan keterampilan.

Metode EPA adalah pembelajaran yang memperhatikan kemampuan awal siswa sebelum memberikan pengetahuan baru. Metode ini menekankan pada kegiatan pembelajaran yang dilaksanakan dalam tiga tahap yaitu tahap eksplorasi, tahap pengenalan, dan aplikasi konsep.

Pembelajaran dengan metode EPA (Eksplorasi, Pengenalan, dan Aplikasi Konsep) menggunakan pendekatan keterampilan proses. Alasan dari penggunaan keterampilan proses adalah karena adanya ahli psikologi umumnya sependapat bahwa anak-anak muda memahami konsep-konsep yang rumit dan abstrak jika disertai dengan contoh-contoh yang konkrit atau contoh yang sesuai dengan situasi yang dihadapi.

Pendekatan keterampilan proses didefinisikan sebagai upaya untuk mengembangkan keterampilan-keterampilan fisik dan mental anak sehingga anak mampu menemukan dan mengembangkan sendiri fakta dan konsep sehingga menumbuhkan dan mengembangkan sikap dan nilai yang dituntut dalam belajar (Semiwan.dkk, 2010).

Pendekata keterampilan proses (PKP) dapat diartikan sebagai wawasan atau keterampilan-keterampilan intelektual, sosial dan fisik yang bersumber dari kemampuan-kemampuan mendasar yang pada prinsipnya telah ada dalam diri siswa. Dari batasan pendekatan keterampilan proses tersebut, kita memperoleh suatu gambaran bahwa pendekatan keterampilan proses bukan tindakan instruksional yang berada di luar kemampuan siswa (Dimyati, 2006).

\section{METODE PENELITIAN}

Jenis penelitian yang digunakan adalah penelitian tindakan kelas (classroom action research) karena peneliti ini juga terlibat langsung dalam proses belajar mengajar mulai dari awal sampai akhir pelajaran. PTK harus tertuju dan mengenai hal-hal yang terjadi di dalam kelas. Adapun rancangan yang dimaksud adalah tindakan berupa penerapan metode pembelajaran EPA (Eksplorasi, Pengenalan, dan Aplikasi Konsep) dalam meningkatkan hasil belajar siswa materi Operasi Pada Bilangan Pecahan kelas VII-A SMP Negeri 8 Donggo Satap tahun pelajaran 2021/2022.

Pendekatan yang dilakukan dalam penelitian ini adalah pendekatan kuantitatif dan pendekatan kualitatif. Pendekatan kuantitatif diproleh dari hasil evaluasi yang akan memberikan jawaban mengenai berhasil atau tidaknya proses pembelajaran, sedangkan pendekatan kualitatif diperoleh dari hasil observasi yang akan memberikan gambaran tentang kegiatan guru dan siswa terhadap proses pembelajaran. Penelitian ini dilaksanakan di SMP Negeri 8 Donggo Satap Tahun 
pelajaran 2021. Penelitian ini dilakukan selama dua bulan, mulai bulan Juli sampai bulan september 2021.

Adapun rancangan penelitian yang dilakukan dalam penelitian ini dengan menerapkan langkah PTK. Penelitian ini dilaksanakan dalam suatu siklus. Setiap siklus terdiri dari empat tahap yaitu tahap perencanaan, tahap pelaksanaan, tahap observasi, dan tahap refleksi (Arikunto, 2010).

Sebelum melaksanakan tindakan, terlebih dahulu peneliti harus merencanakan secara seksama jenis tindakan yang akan dilakukan. Kedua, setelah rencana disusun secara matang, barulah tindakan dilakukan. Ketiga, bersamaan dengan dilaksanakannya tindakan, peneliti mengamati proses pelaksanaan tindakan itu sendiri serta akibat yang ditimbulkannya. Keempat, berdasarkan hasil pengamatan tersebut, peneliti kemudian melakukan refleksi atas tindakan yang telah dilakukan. Jika hasil refleksi menunjukkan perlunya dilakukan perbaikan atas tindakan yang dilakukan, maka rencana tindakan perlu disepurnakan lagi agar tindakan yang dilaksanakan berikutnya tidak sekedar mengulang apa yang telah diperbuat sebelumnya. Demikian seterusnya sampai masalah yang diteliti dapat dipecahkan secara optimal.

Pada tahapan siklus, pembelajaran yang dilaksanakan sesuai dengan pokok bahasan dengan tahapan:

\section{Perencanaan}

Perencanaan kegiatan yang dilakukan dalam pelaksanaan penerapan metode pembelajaran EPA yaitu mempersiapkan hal-hal sebagai berikut:

a. Mensosialisasikan metode pembelajaran EPA.

b. Menyiapkan skenario pembelajaran menggunakan metode pembelajaran EPA.

c. Menyiapkan pedoman observasi untuk mencatat kegiatan belajar siswa dan kegiatan guru

d. Membuat soal tes awal, LKS dan soal tes belajar.

e. Merencanakan analisis hasil tes.

f. Materi pada siklus I.

\section{Tindakan}

Tahap penelitian ini yaitu: melaksanakan kegiatan belajar mengajar di kelas sesuai dengan skenario pembelajaran yang telah disusun. Guru menyampaikan persepsi tentang jenis-jenis bilangan dengan metode ceramah dan tanya jawab yang diteruskan dengan diskusi kelompok.

a. Mengadakan presensi kehadiran siswa dan mencatat siswa yang absen serta menanyakan alasannya jika ada.

b. Menjelaskan materi pokok penjumlahan konsep pecahan secara klasikal baik menggunakan metode ceramah, bervariasi maupun demonstrasi.

c. Membagikan lembar kerja siswa supaya dikerjakan secara kelompok sesuai dengan kelompoknya masing-masing.

d. Tiap kelompok bekerja sama mengerjakan lembar kerja yang telah diterima, dengan dipimpin ketua kelompok.

e. Membimbing tiap-tiap kelompok secara bergilir waktu mengerjakan atau memaparkan hasilnya di papan tulis.

f. Bersama siswa menyimpulkan atau menanyakan hasil belajar pada materi tersebut.

g. Hasil mengerjakan post tes pada akhir pelajaran, dan mempresentasikan hasilnya. 
h. Siswa diberi pekerjaan rumah yang terkait materi yang belum memenuhi batas tuntas.

\section{Observasi dan Evaluasi}

Kegiatan pada tahap observasi adalah melakukan observasi secara kontinyu setiap kali berlangsungnya pelaksanaan tindakan dengan mengamati pelaksanaan kegiatan belajar mengajar, apakah sesuai dengan skenario pembelajaran. Tahap evaluasi dilakukan setelah akhir setiap siklus dengan memberikan tes berbentuk essay untuk mengetahui pemahaman dan penguasaan siswa terhadap konsep yang telah dipelajari.

\section{Refleksi}

Refleksi dilakukan pada akhir siklus, pada tahap ini peneliti sebagai pengajar bersama guru yang bertindak sebagai obsever mengkaji hasil yang diperoleh dari pemberian tindakan pada tiap siklus. Kegiatan pada tahap refleksi ini juga mengkaji kekurangan dan hambatan yang muncul pada saat berlangsungnya proses belajar mengajar. Sehingga diperoleh alternatif pemecahan masalah yang muncul pada setiap proses belajar mengajar, dan dapat melakukan perbaikan untuk pelaksanaan siklus selanjutnya. Hasil refleksi pada siklus I untuk merencanakan tindakan pada siklus II dan hasil refleksi pada siklus II untuk merencanakan tindakan pada siklus berikutnya.

\section{Instrumen Penelitian}

Instrumen penelitian merupakan alat bantu yang dapat diwujudkan dalam benda, misalnya angket, daftar cocok, pedoman wawancara, lembar/panduan pengamatan, soal tes, dan skala (Trianto, 2010). Instrumen penelitian yang digunakan dalam penelitian ini adalah yang pertama lembar Observasi, dimana lembar obsevasi ini digunakan untuk memperoleh data tentang situasi belajar selama proses pembelajaran berlangsung. Serta untuk mengetahui kesesuaian dengan skenario pembelajaran dan pelaksanaan belajar mengajar di kelas. Kemudian instrumen penelitian yang kedua adalah tes yang diberikan untuk memperoleh data tentang prestasi akademik setiap siklus. Tes ini memuat tentang sub materi operasi pada bilangan pecahan yang akan diberikan pada akhir siklus, kemudian dianalisis secara kuantitatif. Adapun kisi-kisi instrumen soal sebagai berikut :

\section{Analisis Data}

1. Data Hasil Observasi

Data hasil observasi dianalisis dengan melihat adanya deskriptor yang nampak pada lembar observasi guru maupun siswa.

2. Data Tes Hasil Belajar

Setelah memperoleh data tes hasil belajar maka data tersebut dianalisa dengan mencari ketuntasan belajar dan daya serap, kemudian dianalisa secara kuantitatif.

a. Ketuntasan Individu

Setiap siswa dalam proses belajar mengajar dikatakan tuntas apabila memperoleh nilai lebih besar atau sama dengan 6,5 (Depdikbud:2018). Nilai ketuntasan minimal sebesar 6,5 dipilih karena sesuai dengan kemampuan individu, hal ini sesuai dengan standar ketuntasan belajar siswa pada SMP Negeri 8 Donggo Satap.

b. Ketuntasan Klasikal 
Data tes hasil belajar proses pembelajaran dianalisis dengan menggunakan analisis ketuntasan hasil belajar secara klasikal minimal 85\% dari jumlah siswa yang memperoleh nilai 65 keatas. Dengan rumus ketuntasan belajar klasikal adalah:

$$
K K=\frac{N}{N_{1}} \times 100 \%
$$

Keterangan :

$\mathrm{KK}=$ Ketuntasan klasikal

$\mathrm{N}=$ Jumlah siswa yang memperoleh nilai 65 keatas

$\mathrm{N}_{1}$ = Jumlah seluruh siswa

Ketuntasan belajar klasikal tercapai jika $\geq 85 \%$ siswa memperoleh skor minimal 65 yang akan terlihat pada hasil tiap-tiap siklus (Nurkencana: 2000)

\section{HASIL DAN PEMBAHASAN}

Penelitian ini dilaksanakan selama 2 siklus dengan subjek penelitian siswa kelas VII-A SMP Negeri 8 Donggo Satap yang terdiri dari 13 siswa. Penelitian inin dilaksanakan pada mata pelajaran matematika khudusnya materi operasi pada bilangan pecahan dengan menggunakan metode pembelajaran EPA (Eksplorasi, Pengenalan Dan Aplikasi Konsep) Untuk Meningkatkan Hasil Belajar Siswa. Penelitian tindakan kelas di SMP Negeri 8 Donggo Satap dilaksanakan dalam 2 siklus, yaitu siklus pertama selama 2 kali pertemuan dan siklus dua selama 2 kali pertemuan.

\section{Deskripsi Hasil Penelitian Siklus I}

Siklus I dilaksanakan oleh peneliti dalam 2 pertemuan dengan alokasi waktu 2 x 45 menit atau 2 jam pelajaran (masing-masing pertemuan). Siklus I terdiri dari empat tahap, yaitu perencanaan, pelaksanaan tindakan, observasi/evaluasi dan refleksi.

\section{Pertemuan I Siklus I}

\section{a. Tahap Perencanaan}

Pada tahap perencanaan kegiatan dilakukan pelaksanaan penerapan metode pembelajaran EPA yaitu mempersiapkan hal-hal sebagai berikut:

1. Menyiapkan rencana pelaksanaan pembelajaran (RPP)

2. Menyiapkan mata pelajaran yang diajarkan

3. Menyiapkan LKS

4. Menyiapkan lembar observasi aktifitas guru

5. Menyiapkan lembar observasi aktifitas siswa

6. Menyiapkan soal evaluasi

Peneliti mensosialisasikan penerapan metode pembelajaran EPA (Eksplorasi, Pengenalan dan Aplikasi Konsep) Kepada guru matematika kelas VII-A SMP Negeri 8 Donggo Satap.

\section{b. Tahap pelaksanaan tindakan}

\section{Pendahuluan}

Pada awal pertemuan pertama guru mengucapkan salam dan kemudian mengecek kehadiran siswa, selanjutnya guru melakukan observasi kesiapan siswa dalam menerima pembelajaran. Pelaksanaan tindakan pada siklus I dilaksanakan 
pada tanggal 17 Juli dan 22 Juli 2021. Masing-masing pertemuan berlangsung selama 2 jam pelajaran $(2 \times 45)$ di kelas VII-A SMP Negeri 8 Donggo satap. Dalam hal ini proses pembelajaran di laksanakan dengan mengacu pada RPP yang telah dibuat sesuai yang akan diajarkan. Pada proses pembelajaran, sesuai dengan kesepakatan bahwa peneliti bertindak sebagai guru dan guru mata pelajaran matematika bertindak sebagai observer.

2. Kegiatan Inti

Kegiatan yang dilakukan pada tahap ini adalah melaksanakan kegiatan belajar mengajar di kelas sesuai dengan rencana pelaksanaan pembelajaran pertemuan pertama yang sudah di rencanakan, yaitu penyampaian materi tentang pengertian operasi pada bilangan pecahan.

Secara umum tindakan yang dilakukan untuk setiap pertemuan pada siklus ini adalah:

1. Pengelompokkan siswa sesuai dengan klasifikasi yang didapat dari metode pembelajaran EPA (Eksplorasi, Pengenalan dan aplikasi konsep).

2. Membahas materi pelajaran dengan model pembelajaran EPA (Eksplorasi, Pengenalan dan aplikasi konsep) sesuai dengan rencana yang telah di rancang.

3. Mengintruksikan kepada siswa tinggi untuk belajar sendiri dengan menggunakn buku-buku yang relavan.

4. Memberikan perlakuan kepada kelompok sedang dan rendah dalam pemberian materi.

5. Penyajian materi pelajaran dimula dari yang sederhana.

6. Memberikan umpan balik positif terhadap jawaban dan tanggapan siswa.

7. Melakukan penugasan kepada siswa, baik secara individual maupun kelompok.

8. Dengan memberikan motivasi dan menciptakan interaksi yang harmonis antara guru dan siswa, siswa diarahkan untuk menyelesaikan masalah atau soal yang diberikan.

9. Pada akhir siklus diberikan tes dari materi yang telah di ajarkan untuk mengukur hasil belajar matematika siswa.

\section{Penutup}

Guru bersama dengan siswa membuat kesimpulan dari materi yang telah di sampaikan dan memberikan penguatan terhadap kesimpulan yang di buat oleh siswa.

\section{c. Tahap Observasi}

Pengamatan dalam kegiatan pelaksanaan kegiatan pelaksanaan tindakan berlangsung. Observasi pada siklus I dilakukan guru mata pelajaran matematika kelas VII-A SMP Negeri 8 Donggo dengan mengamati aktivitas belajar siswa dan aktifitas peneliti. Kegiatan observasi dilakukan oleh obsever pada saat proses belajar mengajar berlangsung.

1. Aktivitas Belajar Siswa

Data lengkap mengenai skor aktivitas siswa selama proses pembelajaran pada siklus I Pertemuan 1. Data tersebut diolah sedmikian rupa sehingga diperoleh datadata sebagai berikut: 
Susisusanti dkk, Penerapan Pembelajaran EPA (Eksplorasi, Pengenalan, dan Aplikasi Konsep)...

Tabel 1. Hasil Analisis Lembar Observasi Aktivitas Belajar Siswa Dan Kategori Aktivitas Siswa Dalam Pembelajaran pertemuan I Siklus I

\begin{tabular}{|l|l|c|}
\hline \multirow{2}{*}{ No } & Aspek yang diobservasi & Skor Indikator \\
\cline { 3 - 3 } & & Pertemuan I \\
\hline 1 & Kesiapan siswa dalam mengikuti pelajaran & 2 \\
\hline 2 & Antusiasme kegiatan siswa dalam belajar mengajar & 2 \\
\hline 3 & Timbulnya inisiatif siswa & 2 \\
\hline 4 & Keaktifan siswa & 3 \\
\hline 5 & Keterampilan & 3 \\
\hline 5 & Kerja sama kelompok dalam berdiskusi & 2 \\
\hline Jumlah skor & 14 \\
\hline Nilai rata-rata & 2,33 \\
\hline Total nilai rata-rata & 4,83 \\
\hline Nilai rata-rata siklus I & 2,74 \\
\hline Kategori & Cukup baik \\
\hline
\end{tabular}

Dari Tabel 1 diatas dapat dilihat bahwa jumlah skor yang didapat pada pertemuan pertama adalah 14 dengan nilai rata-rata 2,33 dan sehingga total nilai ratarata 4,83 sehingga masuk pada kategori cukup baik.

2. Aktivitas Guru

Data lengkap mengenai skor ativitas guru selama proses pemblajaran matematika materi operasi pada bilngan pecahan pada siklus I (pertemuan 1 dan 2). Data obsrvasi gurubdan siswa dapat dilihat pada lembar hasil observasi guru dan siswa siklus I. Data tersebut di olah sedemikian rupa sehingga diperoleh data-data sebagai berikkut:

Tabel 2. Hasil Analisis Aktivitas Guru Dalam Pembelajaran Siklus I

\begin{tabular}{|l|l|c|}
\hline No & Aspek yang diobservasi & Skor Indikator \\
\cline { 2 - 3 } & & Pertemuan I \\
\hline 1 & Membandingkan minat dan motivasi siswa dalam belajar & 3 \\
\hline 2 & pemberian apresiasi kepada siswa & 2 \\
\hline 3 & Penyampaian materi kepada siswa & 2 \\
\hline 4 & Penggunaan pembelajaran metode EPA & 3 \\
\hline 5 & $\begin{array}{l}\text { Bersama-sama siswa membuat kesimpulan dengan } \\
\text { bahasa sendiri }\end{array}$ & 3 \\
\hline 6 & Mengatur strategi dengan metode pembelajaran EPA & 2 \\
\hline Jumlah skor & 15 \\
\hline Nilai rata-rata & 2,50 \\
\hline Total nilai rata-rata & 5,16 \\
\hline Nilai rata-rata siklus I & 2,58 \\
\hline Kategori & Cukup baik \\
\hline
\end{tabular}

Dari Tabel 2 diatas dapat dilihat bahwa jumlah skor yang didapat pada pertemuan pertama adalah 15 dengan nilai rata-rata 2,50 dan sehingga total nilai ratarata 5,16 sehingga masuk pada kategori cukup baik. 


\section{d. Tahap refleksi}

Kegiatan refleksi dilaksanakan pada akhir siklus I pertemuan 2 yakni hari senin 12 agustus 2021 dengan memberikan tes evaluasi hasil belajar kepada siswa. Kegiatan ini berlangsung selama 1 x 50 menit. Bentuk soal adalah essay sebanyak 5 soal untuk di kerjakan secara individu. Jawaban siswa kemudian di periksa dengan skor maksimal 100 jika semua jawaban siswa benar dan skor minimal 0 jika siswa tidak menjawab sama sekali. Data lengkap hasil belajar siswa dapat di lihat pada tabel evaluasi hasil belajar siswa siklus I. Data tersebut di olah sedemikian rupa sehingga diperoeh data-data sebagai berikut :

Tabel 3. Data Analisis tes evaluasi hasil belajar siklus I pada siswa kelas VII-A SMP Negeri 8 Donggo Satap tahun 2021/2022

\begin{tabular}{|l|l|c|}
\hline No & Hasil Evaluasi & Keterangan \\
\hline 1 & Jumlah siswa & 13 \\
\hline 2 & jumlah siswa yang memperoleh nilai $\geq 65$ & 8 siswa \\
\hline 3 & Jumlah siswa yang memperoleh nilai $<65$ & 5 siswa \\
\hline 4 & Rata-rata nilai siswa & 69,28 \\
\hline 5 & Presentasi ketuntasan & $64,28 \%$ \\
\hline
\end{tabular}

Dari Tabel 3 di atas dapat disimpulkan bahwa hasil evaluasi siswa 69,28 dan presentasi siswa yang mendapat nilai $\geq 65$ atau telah mencapai ketuntasan belajar adalah 64,28\%. Dari data hasilbelum tercapai karena hanya mencapai 64,28\% saja,sementara ketuntasan klasikal itu dapat tercapai apabila presentase ketuntasan yang masih belum tuntas secara maksimal, memang diakui bahwa ke 5 siswa tersebut adalah siswa yang cukup lambat dalam menerima pelajaran terutama pelajaran matematika. Sehingga penelitian ini akan di lanjutkan pada siklus II.

\section{Pertemuan II Siklus I}

\section{a. Tahap Perencanaan}

1. Merancang perangkat pembelajaran.

2. Membuat rencana pelaksanaan pembelajaran.

3. Menyusun instrumen tes untuk mengukur peningkatan hasil belajar siswa.

4. Mempersiapkan Lembar Kerja Siswa.

5. Mempersiapkan alat, bahan, dan media pembelajaran.

\section{b. Tahap Pelaksanaan tindakan}

1. pendahuluan

Pelaksanaan tindakan pada siklus I dilaksanakan pada tanggal 11 Dan 14 agustus 2021. Masing-masing pertemuan berlangsung selama 2 jam pelajaran $(2 \mathrm{x}$ 45) di kelas VII-A SMP Negeri 8 Donggo satap. Dalam hal ini proses pembelajaran di laksanakan dengan mengacu pada RPP yang telah dibuat sesuai yang akan diajarkan. Pada proses pembelajaran, sesuai dengan kesepakatan bahwa peneliti bertindak sebagai guru dan guru mata pelajaran matematika bertindak sebagai observer.

2. Kegiatan Inti

Kegiatan pembelajaran diawali dengan persiapan siswa secara fisik dan pengkodisian kelas. Setelah siswa dirasa sudah siap untuk menerima pembelajaran hari ini, guru mengucapkan salam dan membaca do,a kemudian memeriksa keahdiran siswa. Dengan bimbingan guru, siswa diajak untuk mengingat kembali materi yang telah di pelajari sebelumnya. Setelah itu guru menyapaikan tujuan pembelajaranyan yang terkait dengan materi operasi pada bilangan pecahan. 
Setelah itu guru ingin mereview pengetahuan siswa pada matematika dasar. Dengan memberikan pertanyaan secara acak kepada siswa, guru dapat menyimpulkan bahwa pengetahuan siswa terhadap perkalian dasar cukup baik. Kegiatan selanjutnya Guru membagi siswa menjadi 3 kelompok kecil dengan komposisi setiap kelompok terdiri dari 4 - 5 siswa. Kemudian guru memberikan Contoh yang terkait dengan materi operasi pada bilangan pecahan untuk mengerjakan soal yang diberikan oleh guru pelajaran. guru menyuruh siswa untuk menjelaskan dengan menggunakan contoh yang diajarkan sebelumnya. Setelah waktu habis guru membimbing seluruh siswa untuk mengumpulkan LKS.

3. Penutup

Diakhir kegiatan pembelajaran guru bersama siswa menyimpulkan pembelajarn hari ini dan memberikan pengarahan untuk mempersiapkan diri pada pertemuan selanjutnya yaitu melanjutkan persentasi bagi kelompok yang belum mempersentasikan hasil diskusi, dan mengadakan evaluasi dengan sejumlah soal 5 butir serta memberikan motivasi kepada siswa. Selanjutnya guru memotivasi siswa agar lebih memperhatikan pembelajaran pada pertemuan selanjutnya.

\section{c. Tahap Observasi}

Pengamatan dalam kegiatan pelaksanaan kegiatan pelaksanaan tindakan berlangsung. Observasi pada siklus I dilakukan guru mata pelajaran matematika kelas VII-A SMP Negeri 8 Donggo dengan mengamati aktivitas belajar siswa dan aktifitas peneliti. Kegiatan observasi dilakukan oleh obsever pada saat proses belajar mengajar berlangsung. Data observasi guru dan siswa siklus I. Data tersebut dianalisis sebagai berikut :

1. Aktivitas Belajar Siswa

Data lengkap mengenai skor aktivitas siswa selama proses pembelajaran dengan menggunakan alat peraga pada siklus I pertemuan 2. Data tersebut diolah sedmikian rupa sehingga diperoleh data-data sebagai berikut :

Tabel 4. Hasil Analisis Lembar Observasi Aktivitas Belajar Siswa Dan Kategori Aktivitas Siswa Dalam Pembelajaran pertemuan II Siklus I

\begin{tabular}{|l|l|c|}
\hline No & Aspek yang diobservasi & Skor Indikator \\
\cline { 3 - 3 } & & Pertemuan II \\
\hline 1 & Kesiapan siswa dalam mengikuti pelajaran & 3 \\
\hline 2 & Antusiasme kegiatan siswa dalam belajar mengajar & 2 \\
\hline 3 & Timbulnya inisiatif siswa & 3 \\
\hline 4 & Keaktifan siswa & 2 \\
\hline 5 & Keterampilan & 2 \\
\hline 5 & Kerja sama kelompok dalam berdiskusi & 3 \\
\hline Jumlah skor & 15 \\
\hline Nilai rata-rata & 2,50 \\
\hline Total nilai rata-rata & 4,83 \\
\hline Nilai rata-rata siklus I & 2,74 \\
\hline Kategori & Cukup baik \\
\hline
\end{tabular}

Dari Tabel 4 diatas dapat dilihat bahwa jumlah skor yang didapat pada pertemuan pertama adalah 15 dengan nilai rata-rata 2,50 dan sehingga total nilai rata-rata 4,83 sehingga masuk pada kategori cukup baik.

2. Aktivitas Guru 
Data lengkap mengenai skor ativitas guru selama proses pemblajaran matematika materi operasi pada bilngan pecahan pada siklus I (pertemuan 1 dan 2). Data obsrvasi gurubdan siswa dapat dilihat pada lembar hasil observasi guru dan siswa siklus I. Data tersebut di olah sedemikian rupa sehingga diperoleh datadata sebagai berikkut :

Tabel 5. Hasil Analisis Aktivitas Guru Dalam Pembelajaran Siklus I pertemuan II

\begin{tabular}{|l|l|c|}
\hline No & Aspek yang diobservasi & Skor Indikator \\
\cline { 3 - 3 } & & Pertemuan II \\
\hline 1 & Membandingkan minat dan motivasi siswa dalam belajar & 3 \\
\hline 2 & pemberian apresiasi kepada siswa & 3 \\
\hline 3 & Penyampaian materi kepada siswa & 2 \\
\hline 4 & Penggunaan pembelajaran metode EPA & 2 \\
\hline 5 & $\begin{array}{l}\text { Bersama-sama siswa membuat kesimpulan dengan bahasa } \\
\text { sendiri }\end{array}$ & 3 \\
\hline 6 & Mengatur strategi dengan metode pembelajaran EPA & 2 \\
\hline Jumlah skor & 16 \\
\hline Nilai rata-rata & 2,66 \\
\hline \multicolumn{2}{|l}{ Total nilai rata-rata } & 5,16 \\
\hline Nilai rata-rata siklus I & 2,58 \\
\hline Kategori & Cukup baik \\
\hline
\end{tabular}

Dari Tabel 5 diatas dapat dilihat bahwa jumlah skor yang didapat pada pertemuan pertama adalah 16 dengan nilai rata-rata 2,66 sehingga total nilai ratarata 5,16 sehingga masuk pada kategori cukup baik.

\section{d. Tahap Refleksi}

Tahap ini merupakan kegiatan yang dilakukan untuk melihat kekurangankekurangan kegiatan pembelajaran dari data observasi,dengan tujuan untuk memperbaiki kegiatan pada pertemuan siklus selanjutnya. Dari hasil belajar siswa sebesar 69,28 dengan prentase ketuntasan belajar siswa sebesar 64,28\% dan termasuk dalam kategori cukup. Nilai tersebut belum mencapai kriteria indikator keberhasilan yang telah di tentukan pada bab selanjutnya. Hasil dari observasi aktivitas guru memperoleh nilai sebesar 2,83 dan termasuk kategori baik, namun peneliti menginginkan adanya perbaikan karena peneliti merasa masih terdapat beberapa kenadala yang terjadi pada pembelajaran. Hal ini disebabkan karena terdapat beberapa kegiatan yang belum terlaksana dan belum dilakukan dengan maksimal, kurangnya kemampuan guru dalam mengelola waktudan kurangnya penyesuaian guru dikelas. Hasil pengamatan aktivitas siswa memperoleh nilai sebesar 2,34. Nilai tersebut sudah termasuk kategori cukup baik, namun peneliti menginginkan adanya perabaikan karena peneliti merasa masih terdapat beberapa kendala yang terjadi pada pembelajaran. Kendala yang terjadi antara lain, saat berdoa masih terdapat beberapa siswa yang tidak serius, beberapa siswa kurang memperhatikan ketika guru menerangkan didepan, siswa kurang percaya diri ketika tampil didepan kelas dan tidak kondusif dalam diskusi kelompok.

\section{Deksripsi Hasil Penelitian Siklus II}

\section{Pertemuan I Siklus II}


Pelaksnaan siklus II ini tidak jauh berada dengan siklus I karena siklus II dilaksanakan sebagai perbaikan siklus I.

\section{a. Tahap Perencanaan}

Tahap perencanaan diawali dengan penentuan waktu yang akan digunakan untuk melaksanakam penelitian. Pada tahap ini peneliti menyiapkan RPP yang digunakan sebelumnya pada siklus I. Peneliti tidak melakukan perbaikan pada kegiatan awal dan kegiatan penutup, hanya lebih mengoptimalkan pada saat pelaksnaan siklus II sesuai dengan waktu yang telah ditentukan. Peneliti hanya melakukan perbaikan pada kegiatan inti pembelajaran, yakni dengan memaksimalkan waktu yang digunakan untuk diskusi agar siswa lebih memahami materi operasi pada bilangan peacahan dalam menyelesaikan soal yang diberikan.

\section{b. Tahap Pelaksanaan tindakan}

1. Pendahuluan

Tindakan pada siklus II dilaksanakan pada tanggal 12 dan 14 agustus 2021. Tahap tindakan pada siklus II dilaksanakan sesuai dengan rencana pelaksanaan pembelajaran (RPP) yang telah disusun. Masing-masing pertemuan berlangsung selama 2 x 45 menit. Kegiatan pembelajaran diawali dengan persiapan siswa seacra fisik dan pengkondisian kelas. Guru memulai pembelajaran dengan mengucapkn salam dan membaca do,a kemudian memeriksa kehadiran. Dengan bimbingan guru, siswa diajak untuk mengingat kembali materi yang telah di pelajari sebelumnya, yaitu pada saat dilaksanakan siklus sebelumnya. Setelah itu siswa menerima informasi mengenai tujuan pembelajaran dan kegiatan pembelajaran hari ini yang akan di pelajari berasama guru.

2. Kegiatan Inti

Kegiatan inti dimulai dengan guru membagi siswa menjadi 3 kelompok kecil dengan komposisi setiap kelompok terdiri dari 4-5 siswa. Pembagian kelompok ditentukan oleh guru sesuai dengan kemampuan masing-masing siswa berdasarkan hasil belajar yang didapat saat siklus I. Kemudian guru menjelaskan materi operasi pada bialngan pecahan. Kemudian guru menyuruh siswa untuk mengejarkan soal pada LKS dan kemudian memadukan hasil pengerjaan dengan contoh yang dipaparkan oleh guru sebelumnya pada siklus I, Guru menyuruh kelompok yang sudah selesai untuk mempersentasikan di depan kelompok yang lain, peneliti menyuruh siswa untuk menjelaskan dengan kalimat mereka sendiri. Setelah waktu habis, guru membimbing seluruh siswa untuk mengumpulkan lembar kerja yang telah dikerjakan.

3. Penutup

Guru melakukan evaluasi dengan cara tanya jawab materi yang telah dipelajari, kemudian menyuruh siswa membuat kesimpulan dengan bahasa dan cara mereka sendiri dari materi yang telah di pelajari sambil membimbingnya kemudian guru menutup pelajaran dengan berdoa bersama.

\section{c. Tahap Observasi}

Observasi pada siklus II dilakukan oleh guru mata pelajaran matematika kelas VII-A SMP Negeri 8 Donggo dengan mengamati aktivitas peneliti dan siswa selama proses belajar mengajar. Data observasi guru dan siswa dapat dilihat pada lembar hasil observasi guru dan siswa pada pertemuan I siklus II.

1. Aktivitas Belajar Siswa

@ 2021 DIKSI (https://jurnal.bimaberilmu.com/index.php/diksi) 
Data lengkap mengenai skor aktivitas siswa selama proses pembelajaran materi operasi pada bilangan pecahan pada siklus II. Data tersebut diolah sedemikian rupa sehingga diperoleh data-data sebagai berikut :

Tabel 6. Hasil Analisis Lembar Observasi Aktivitas Belajar Siswa Dalam Pembelajaran Siklus II pertemuan I.

\begin{tabular}{|l|l|c|}
\hline No & Aspek yang diobservasi & Skor Indikator \\
\cline { 2 - 3 } & & Pertemuan I \\
\hline 1 & Kesiapan siswa dalam mengikuti pelajaran & 3 \\
\hline 2 & Antusiasme kegiatan siswa dalam belajar mengajar & 2 \\
\hline 3 & Timbulnya inisiatif siswa & 3 \\
\hline 4 & Keaktifan siswa & 2 \\
\hline 5 & Keterampilan & 2 \\
\hline 5 & Kerja sama kelompok dalam berdiskusi & 3 \\
\hline Jumlah skor & 18 \\
\hline Nilai rata-rata & 3,00 \\
\hline Total nilai rata-rata & 6,50 \\
\hline Nilai rata-rata siklus I & 3,25 \\
\hline Kategori & Aktif \\
\hline
\end{tabular}

Dari Tabel 6 diatas dapat dilihat bahwa jumlah skor yang didapat pada pertemuan I pada siklus II adalah 18 dengan nilai rata-rata 3,00 dan sehingga total nilai rata-rata 6,50 sehingga masuk pada kategori aktif.

2. Aktivitas Guru

Data lengkap mengenai skor aktivitas guru selama prose.s pembelarajaran matematika materi operasi pada bilangan pecahan pada siklus II. Data obsrvasi guru dan siswa dapat dilihat pada lembar hasil observasi guru dan siswa siklus II. Data tersebut diolah sedemikian rupa sehingga diperoleh data-data sebagai berikut:

Tabel 7. Analisis data aktivitas guru dalam pembelajaran siklus II pertemuan I

\begin{tabular}{|l|l|c|}
\hline No & Aspek yang diobservasi & Skor Indikator \\
\cline { 3 - 3 } & & Pertemuan II \\
\hline 1 & Membandingkan minat dan motivasi siswa dalam belajar & 3 \\
\hline 2 & pemberian apresiasi kepada siswa & 3 \\
\hline 3 & Penyampaian materi kepada siswa & 3 \\
\hline 4 & Penggunaan pembelajaran metode EPA & 4 \\
\hline 5 & $\begin{array}{l}\text { Bersama-sama siswa membuat kesimpulan dengan bahasa } \\
\text { sendiri }\end{array}$ & 3 \\
\hline 6 & Mengatur strategi dengan metode pembelajaran EPA & 3 \\
\hline Jumlah skor & 18 \\
\hline Nilai rata-rata & 3,00 \\
\hline \multicolumn{2}{|l}{ Total nilai rata-rata } & 6,16 \\
\hline Nilai rata-rata siklus II & 3,08 \\
\hline Kategori & Baik \\
\hline
\end{tabular}

Dari Tabel 7 diatas dapat dilihat bahwa jumlah skor yang didapat pada pertemuan I siklus II adalah 18 dengan nilai rata-rata 3,00 sehingga total nilai rata-rata 6,16 sehingga masuk pada kategori Baik.

\section{d. Tahap Refleksi}


Setelah melalui tahapan pelaksanaan serta tahan observasi dan diakhiri dengan evaluasi hasil belajar siswa maka selanjutnya dilakukan tahap refleksi.

Adapun kekurangan-kekurangan dalam kegiatan pembelajaran disajikan seabagai berikut :

Tabel 8. Data Hasil Refleksi Siklus II

\begin{tabular}{|ll|l|}
\hline \multicolumn{2}{|c|}{ Refleksi } & \multicolumn{1}{|c|}{ Perbaikan } \\
\hline 1) $\begin{array}{l}\text { Kurangnya kemampuan guru dalam } \\
\text { mengelola waktu dan kurangnya } \\
\text { penyesuaian guru terhadap siswa dikelas. }\end{array}$ & $\begin{array}{l}\text { Melaksanakan kegiatan sesuai } \\
\text { dengan alokasi waktu yang pada } \\
\text { RPP yang telah ditentukan. }\end{array}$ \\
\hline 2) & $\begin{array}{l}\text { Masih ada siswa yang belum berani } \\
\text { untuk tampil didepan kelas, baik dalm } \\
\text { penyampaian hasil diskusi maupun dalam } \\
\text { mengerjakan soal dipapan tulis. }\end{array}$ & $\begin{array}{l}\text { Guru hendaknya memberi } \\
\text { motivasi kepada siswa agar } \\
\text { siswa tidak minder }\end{array}$ \\
\hline 3) & $\begin{array}{l}\text { Masih terdapat siswa yang ribut saat } \\
\text { proses presentasi antar kelompok. }\end{array}$ & $\begin{array}{l}\text { Guru hendaknya sedikit lebih } \\
\text { tegas lagi }\end{array}$ \\
\hline 4) $\begin{array}{l}\text { Sebagian siswa masih sangat sulit } \\
\text { memahami materi }\end{array}$ & $\begin{array}{l}\text { Mencari cara untuk siswa dapat } \\
\text { memhami materi. }\end{array}$ \\
\hline
\end{tabular}

\section{Pertemuan II Siklus II}

\section{a. Tahap perencanaan}

1. Merancang perangkat pembelajaran.

2. Membuat rencana pelaksanaan pembelajaran.

3. Menyusun instrumen tes untuk mengukur peningkatan hasil belajar siswa.

4. mempersiapkan Lembar Kerja Siswa.

5. Mempersiapkan alat, bahan, dan media pembelajaran.

\section{b. Tahap Pelaksanaan tindakan}

1. Pendahuluan

Pada awal pembelajaran guru terlebih dahulu mengkondisikan kelas. Guru memulai pembelajaran dengan mnegucapakan salam dan membaca doa kemudian memeriksa kehadiran siswa. Kemudian guru memberikan soal evaluasi berupa soal essay yang terdiri dari 5 butir soal. Pada akhir pertemuan guru mengumpulkan pekerjaan siswa dan menutup pembelajaran.

2. Kegiatan Inti

Pada tahap ini guru mengajar materi sifat-sifat operasi pada bilangan pecahan. Setelah materinya disampaikan guru memberikan kesempatan kepada siswa untuk bertanya mengenai materi yang belum mereka pahami ataupun memberikan tanggapan mengenai materi yang telah disampaikan. Pada pertemuan pertama siklus II ini meskipun masih ada sebagaian dari siswa yang ribut dan kurang memperhatikan penjelasan dari guru namun ada juga peningkatan siswa yang mulai aktif untuk memberikan tanggapan dan bertanya mengenai materi yang belum dipahaminya. Selain itu aktivitas guru pun sudah mulai meningkat mulai dari menanyakan materi yang akan dipelajari, menyampaiakan tujuan pembelajaran dan menegur dengan tegas siswa yang ribut disaat proses pembelajaran berlangsung. Selanjutnya guru memberikan soal untu dikerjakan secara berkelompok masingmasing.

3. Penutup 
Pada tahap ini guru mengajar materi operasi pada bilanagan pecahan. Setelah materinya disampaikan guru memberikan kesempatan kepada siswa untuk bertanya mengenai materi yang belum mereka pahami ataupun memberikan tanggapan mengenai materi yang telah disampaikan. Pada pertemuan pertama siklus II ini meskipun masih ada sebagaian dari siswa yang ribut dan kurang memperhatikan penjelasan dari guru namun ada juga peningkatan siswa yang mulai aktif untuk memberikan tanggapan dan bertanya mengenai materi yang belum dipahaminya. Selain itu aktivitas guru pun sudah mulai meningkat mulai dari menanyakan materi yang akan dipelajari, menyampaiakan tujuan pembelajaran dan menegur dengan tegas siswa yang ribut disaat proses pembelajaran berlangsung. Selanjutnya guru memberikan soal untu dikerjakan secara berkelompok masing-masing.

\section{c. Tahap Observasi}

Observasi pada siklus II dilakukan oleh guru mata pelajaran matematika kelas VII-A SMP Negeri 8 Donggo dengan mengamati aktivitas peneliti dan siswa selama proses belajar mengajar. Data observasi guru dan siswa dapat dilihat pada lembar hasi observasi guru dan siswa pada pertemuan II siklus II.

1. Aktivitas Belajar Siswa

Data lengkap mengenai skor aktivitas siswa selama proses pembelajaran materi operasi pada bilangan pecahan pada siklus II. Data tersebut diolah sedemikian rupa sehingga diperoleh data-data sebagai berikut :

Tabel 9. Hasil Analisis Lembar Observasi Aktivitas Belajar Siswa Dalam Pembelajaran Siklus II pertemuan II.

\begin{tabular}{|l|l|c|}
\hline \multirow{2}{*}{ No } & Aspek yang diobservasi & Skor Indikator \\
\cline { 3 - 3 } & & Pertemuan II \\
\hline 1 & Kesiapan siswa dalam mengikuti pelajaran & 4 \\
\hline 2 & Antusiasme kegiatan siswa dalam belajar mengajar & 4 \\
\hline 3 & Timbulnya inisiatif siswa & 3 \\
\hline 4 & Keaktifan siswa & 3 \\
\hline 5 & Keterampilan & 4 \\
\hline 5 & Kerja sama kelompok dalam berdiskusi & 3 \\
\hline Jumlah skor & 21 \\
\hline Nilai rata-rata & 3,50 \\
\hline Total nilai rata-rata & 6,50 \\
\hline Nilai rata-rata siklus II & 3,25 \\
\hline Kategori & Aktif \\
\hline
\end{tabular}

Dari Tabel 9 diatas dapat dilihat bahwa jumlah skor yang didapat pada pertemuan II pada siklus II adalah 21 dengan nilai rata-rata 3,50 dan sehingga total nilai rata-rata 6,50 sehingga masuk pada kategori aktif.

2. Aktivitas Guru

Data lengkap mengenai skor aktivitas guru selama prose.s pembelarajaran matematika materi operasi pada bilangan pecahan pada siklus II. Data obsrvasi guru dan siswa dapat dilihat pada lembar hasil observasi guru dan siswa siklus II .Data tersebut diolah sedemikian rupa sehingga diperoleh data-data sebagai berikut:

Tabel 10. Analisis data aktivitas guru dalam pembelajaran siklus II Pertemuan II

\begin{tabular}{|l|l|c|}
\hline No & Aspek yang diobservasi & Skor Indikator \\
\cline { 3 - 3 } & & Pertemuan II \\
\hline 1 & Membandingkan minat dan motivasi siswa dalam belajar & 3 \\
\hline
\end{tabular}




\begin{tabular}{|l|l|c|}
\hline 2 & pemberian apresiasi kepada siswa & 3 \\
\hline 3 & Penyampaian materi kepada siswa & 3 \\
\hline 4 & Penggunaan pembelajaran metode EPA & 4 \\
\hline 5 & $\begin{array}{l}\text { Bersama-sama siswa membuat kesimpulan dengan } \\
\text { bahasa sendiri }\end{array}$ & 3 \\
\hline 6 & Mengatur strategi dengan metode pembelajaran EPA & 3 \\
\hline Jumlah skor & 19 \\
\hline Nilai rata-rata & 3,16 \\
\hline Total nilai rata-rata & 6,16 \\
\hline Nilai rata-rata siklus II & 3,08 \\
\hline Kategori & Baik \\
\hline
\end{tabular}

Dari Tabel 10 diatas dapat dilihat bahwa jumlah skor yang didapat pada pertemuan I siklus II adalah 18 dengan nilai rata-rata 3,16 sehingga total nilai ratarata 6,16 sehingga masuk pada kategori Baik.

\section{d. Tahap refleksi}

Kegiatan refleksi dilaksanakan pada akhir pertemuan 2 yakni hari sabtu,16 agustus 2021 dengan memberikan tes evaluasi hasil belajar kepada siswa. Kegiatan ini berlangsung selama 1 x 50 meni. Bentuk soal adalah essay sebanyak 5 soal untuk dikerjakan secara individu. Jawaban siswa kemudian di periksa dengan skor maksimal 100 jika semua jawaban siswa benar dan skor minimal 0 jika siswa tidak menjawab sama sekali. Data lengkap hasil belajar siswa dapat dilihat pada tabel evaluasi hasil belajar siswa siklus II. Data tersebut diolah sedemikian rupa sehingga diperoleh data-data sebagai berikut:

Tabel 11. Data Analisis tes evaluasi hasil belajar siklus II pada siswa kelas VIIA SMP Negeri 8 Donggo Satap tahun 2021/2022

\begin{tabular}{|l|l|c|}
\hline No & Hasil Evaluasi & Keterangan \\
\hline 1 & jumlah siswa yang memperoleh nilai $\geq 65$ & 13 siswa \\
\hline 2 & Jumlah siswa yang memperoleh nilai $<65$ & 1 siswa \\
\hline 3 & Rata-rata nilai siswa & 84,04 \\
\hline 4 & Presentasi ketuntasan & $85,05 \%$ \\
\hline
\end{tabular}

Hasil evaluasi siklus II Menunjukan bahwa nilai rata-rata siswa adalah 84,04 dan presentase siswa yang mendapat nilai $\geq 65$ atau telah mencapai ketuntasan belajar adalah 85,05\%. Dari data hasil evaluasi belajar ini dapat disimpulkan bahwa ketuntasan klasikalnnya telah tercapai yaitu sebesar dan telah memperoleh presentase dan memenuhi indikator keberhasilan.

\section{KESIMPULAN}

Berdasarkan hasil penelitian dan pembahasan dapat disimpukan bahwa penerapan metode Pembelajaran EPA (Eksplorasi,Pengenalan Dan Aplikasi Konsep) dapat meningkatkan hasil belajar matematika materi operasi pada bilangan pecahan siswa kelas VII-A SMP Negeri 8 Donggo Satap tahun pelajaran 2021/2022. Hal ini dilihat dari pengamatan mengalami peningkatan dari rata-rata keseluruhan skor 2,58 (kategori cukup aktif) pada siklus I menjadi 3,08 (kategori aktif) pada siklus II.

Penerapan metode pembelajaran EPA (Ekplorasi, Pengenalan, dan Aplikasi Konsep) pada materi operasi pada bilangan pecahan dapat meningkatkan hasil belajar matematika siswa kelas VII-A SMP Negeri 8 Donggo Satap tahun pelajaran 
2021/2022. Peningkatan ini dapat dilihat dari presentase ketuntasan klasikal siswa sebesar $73,33 \%$ pada siklus I dengan nilai rata-rata 68,26 yang meningkat menjadi $90,00 \%$ pada siklus II dengan nilai rata-rata 72,5 dan telah mencapia indikator keberhasilan yaitu $\geq 85 \%$ siswa mendapat nilai minimal 65 .

\section{DAFTAR PUSTAKA}

Adi, S. (2011). Psikologi Belajar. Jakarta : PT. Renika Cipta

Aqib, Z. (2010). Metode Penelitian Pendidikan, (Jepara: Institut Islam Nahdatul Ulama).

Arikunto, S. (2010). Penelitian Tindakan Kelas. Jakarta : PT. Renika Cipta.

Atmarita, A., \& Syarifuddin, S. (2021). Visual Processing Assessment on Children: A Pilot Study. Jurnal Pendidikan dan Pembelajaran Indonesia (JPPI), 1(1), 1-9.

Depdikbud:(2018). Pembelajaran dan Hasil Pembelajaran Ketuntasan Siswa. PT. Universitas Terbuka.

Depdiknas, (2004). Strategi Belajar Mengajar. PT. Univesitas Terbuka.

Dimyati, (2006). Prinsip-prinsip dan Teknik Evaluasi Pengajaran (Bandung : PT. Remaja Rosdakarya).

Smaldino, (2011). Psikologi Pendidikan, (Yokyakarta : Pustaka Pelajar).

Dusalan, D., Mikrayanti, M., Basrin, B., Jauhari, R. S., \& Furqan, M. (2020). Meningkatkan Aktivitas dan Prestasi Belajar Siswa melalui Metode Index Card Match padaa Materi Pokok Persegi dan Persegi Panjang Kelas VII-b SMP Negeri 1 Wera Tahun Pelajaran 2019/2020. DIKSI: Jurnal Kajian Pendidikan dan Sosial, 1(1), 44-65.

Dwi, F. H. (2008). Strategi Pembelajaran : Teori dan Aplikasi, (Jokjakarta : Ar-ruzz Media).

Hamalik, O. (2010). Penerapan Model Pembelajaran EPA Untuk Meningkatkan Hasil Belajar Matematika Materi Segi Empat Siswa Kelas VII SMPN 1Darul Imarah Aceh Besar. ETD.

Hamdani. (2011). Penerapan Model Pembelajaran EPA Untuk Meningkatkan aktivitas dan Hasil Belajar. jurnal Media Pendidikan Matematika.

Imayanti, I., Syarifuddin, S., \& Mikrayanti, M. (2021). Analisis Proses Berpikir Kritis Siswa dalam Pemecahan Masalah Relasi dan Fungsi pada Siswa SMP. DIKSI: Jurnal Kajian Pendidikan dan Sosial, 2(1), 1-8.

Maghfiroh, N. (2010). Penerapan Pembelajaran EPA Untuk Meningkatkan Hasil dan Efektivitas Belajar. Prosiding Seminar Nasional II APPPI NTB.

Murtalib, M., Gunawan, G., Mutmainah, M., Nurwadani, P. A., \& Almahira, A. (2020). Penerapan Model Pembelajran Kooperatif Tipe NHT (Numbered Head Together) untuk Meningkatkan Aktivitas dan Prestasi Belajar Siswa Materi Pokok Segiempat Kelas VII-4 Semester II SMP Negeri 1 Madapangga Tahun Pelajaran 2019/2020. DIKSI: Jurnal Kajian Pendidikan dan Sosial, 1(1), 12-30. 
Susisusanti dkk, Penerapan Pembelajaran EPA (Eksplorasi, Pengenalan, dan Aplikasi Konsep)...

Nurkencana, (2000). Penelitian Kualitatif dan Kuantitatif. PT. Grenmedia.

Nurwadani, P. A., Syarifuddin, S., Gunawan, G., \& Dusalan, D. (2021). Hubungan Model Pembelajaran Kooperatif Tipe Numbered Head Together (NHT) terhadap Minat dan Hasil Belajar Siswa di Kelas VII SMP Negeri 4 Kota Bima Tahun Pelajaran 2021/2022. DIKSI: Jurnal Kajian Pendidikan dan Sosial, 2(1), 25-38.

Purwanto, (2011). Metode Penelitian Pendidikan Untuk UIN, STAIN, PT AIS, (Bandung, Pustaka Setia).

Sartika, D., Baeti, N., Saifullah, S., Tunisah, A., \& Furahman, R. (2020). Pembelajaran Berbasis Kontekstual dalam Meningkatkan Aktivitas dan Prestasi Belajar Siswa pada Materi Pokok Segitiga di Kelas VII SMP Negeri 2 Bolo Tahun 2019/2020. DIKSI: Jurnal Kajian Pendidikan dan Sosial, 1(2), 107-122.

Semiwan dkk. (2010). Belajar dan Faktor-faktor Yang Mempengaruhinya (Jakarta: Renika Cipta.

Simangunsong, W. \& Sukino, (2006). Model Pembelajaran Inovatif Serta Penerapannya Pada SD/SMP CI-BI (Semarang : Universitas Negeri Semarang).

Slameto. (2010). Belajar. Jakarta : PT. Renika Cipta.

Sudjana, (2009). Model Pembelajaran Menciptakan Proses Belajar Mengajar Yang Kreatif dan Evaktif, (Jakarta : Bumi Aksara).

Sudjana. (2009). Pemelihan Model-model Pembelajaran dan Penerapannya Disekolah, (Semarang :FAK. Tarbiah IAIN Walisongo.

Surakhmad, W. \& Jemmars, (2020). Interaksi Belajar Mengajar. Bandung.

Sutarto, S., Pd, M., Syarifuddin, S. P., \& Pd, M. (2013). Desain Pembelajaran Matematika. Yogyakarta: Samudra Biru.

Syarifuddin, S. (2019). Identifikasi Kesulitan Representasi Matematis Siswa SMP pada Pemecahan Masalah Pecahan.Supermat (Jurnal Pendidikan Matematika), 3(1), 34-42.

Trianto, (2010). Metode Penelitian Kuantitatif Tindakan Kelas (PTK). Jakarta. Renika Cipta.

Winkel, W. (2007). Psikologi Pengajaran. Jakarta. Renika Cipta

Yushniyah, (2010). Strategi Belajar Mengajar. Depdiknas : PT. Univesitas Terbuka.

@ 2021 DIKSI (https://jurnal.bimaberilmu.com/index.php/diksi) 